\title{
Malignant Ampulla of Vater Neoplasm
}

National Cancer Institute

\section{Source}

National Cancer Institute. Malignant Ampulla of Vater Neoplasm. NCI Thesaurus. Code C3536.

A primary or metastatic malignant neoplasm involving the ampulla of Vater. 